\title{
Pullout Characteristics of Geosynthetics Reinforced Earth Using Multilayer Spreading Pullout Test
}

\author{
Jong-Beom Park,, ${ }^{1}$ Daehyeon Kim, ${ }^{2}$ Si-Bong Yang, ${ }^{3}$ and Jang-Heung Kim ${ }^{4}$ \\ ${ }^{1}$ Shinmyeong Construction Technology R\&D Center, Suncheon, Republic of Korea \\ ${ }^{2}$ Department of Civil Engineering, Chosun University, Gwangju, Republic of Korea \\ ${ }^{3}$ Community Planning Team, Jeollanamdo Provincial Government, Muan, Republic of Korea \\ ${ }^{4}$ Shinmyeong Construction Technology, Suncheon, Republic of Korea
}

Correspondence should be addressed to Daehyeon Kim; dkimgeo@chosun.ac.kr

Received 27 January 2017; Accepted 9 May 2017; Published 18 June 2017

Academic Editor: Ying Li

Copyright (C) 2017 Jong-Beom Park et al. This is an open access article distributed under the Creative Commons Attribution License, which permits unrestricted use, distribution, and reproduction in any medium, provided the original work is properly cited.

\begin{abstract}
Pullout test equipment for examining pullout characteristics in a reinforced earth structure is relatively larger than direct shear testing machines and requires much time and expenses in preparing samples. Moreover, because of irregular stress distributions with respect to the length of reinforcements, it is difficult to analyze pullout test results. In this study, we developed a multilayer spreading pullout apparatus enabling the pullout test in the order of a top stage, middle stage, and bottom stage with different loads once a ground model is prepared, suggesting an efficient method of a multilayer spreading pullout test. The pullout test is carried out at least three times with the prepared ground model while changing confining loads. Jumunjin sand was used to verify the developed pullout test apparatus and to analyze pullout characteristics of each reinforcement. The analysis reveals that the difference between angles of pullout friction is approximately 0.86 to $1.3^{\circ}$ which is distributed within the error range of a pullout test. As a result, the multilayer spreading pullout apparatus is applicable as a new pullout apparatus, and the suggested method of multilayer spreading pullout test is identified as a pullout test technique efficiently to obtain pullout parameters.
\end{abstract}

\section{Introduction}

Pullout parameters are generally determined through the pullout test to determine pullout friction or cohesion properties between reinforcements and soil. Many types of pullout apparatuses have been globally developed so far through much study and research. However, since typical pullout apparatuses are larger than most ordinary laboratory test apparatuses, it is very difficult to standardize the pullout apparatuses and method.

Some factors on the pullout test have been the main topic of previous studies and considered as the most important elements in reinforced earth engineering methods. The factors include the boundary condition of the pullout box on the front wall of the pullout apparatuses, the clamp system for connecting reinforcements, the boundary condition between the upper wall and lateral friction, the method of evaluating pullout forces, and the pullout apparatuses.
A small pullout apparatus has length $(L)$, breadth $(B)$, and height $(H)$ of $0.25 \mathrm{~m}, 0.15 \mathrm{~m}$, and $0.15 \mathrm{~m}$ [1], respectively, and a medium one has length $(L)$, breadth $(B)$, and height $(H)$ of $0.6 \mathrm{~m}, 0.4 \mathrm{~m}$, and $0.4 \mathrm{~m}$ [2], respectively. The volume of most large pullout test boxes is approximately 1.0 to $2.0 \mathrm{~m}^{3}$. A large pullout apparatus is sized to have length $(L)$, breadth $(B)$, and height $(H)$ of 1.0 to $2.0 \mathrm{~m}, 0.5$ to $1.2 \mathrm{~m}$, and 0.4 to $1.1 \mathrm{~m}$, respectively, contributing to high manufacturing costs, and requires long test time for earth compaction and disassembly.

Many researchers have studied the method of examining pullout characteristics of reinforcements of a reinforced earth structure, and exemplary test methods related to the pullout test include ASTM D6706 [3], ASTM D5321 [4, 5], and GRI GG5 [6].

Bacot et al. [7], Scholsser and Elias [8], Ingold [9], Sridharan et al. [10], Kata et al. (1991), Rao and Pandey [11], Bathurst et al. [12], Chu and Yin [13], Ezzein and Bathurst [14], Miyata and Bathurst [15], and Ju et al. [16] used pullout apparatuses 
of different sizes to evaluate friction properties of earth/ geosynthetics. Juran and Chen [17] studied pullout test and insisted that the differences in test conditions including used samples or pullout box size have significant impact on the pullout test, which may likely result from qualitative issues rather than quantitative issues of the test.

The ASTM D6706 [3] standard specifies that it is essential to manufacture a soil box of which the breadth is at least $460 \mathrm{~mm}$; the test material is greater than $20 \times D 85$ or $6 \times$ $D$ max; and pullout box length is at least $610 \mathrm{~mm}$ and is five times greater than the maximum size of a geogrid mesh. The pullout speed for controlling a displacement increase shall be between $0.1 \mathrm{~mm} / \mathrm{min}$ [18] and $10 \mathrm{~mm} / \mathrm{min}$ [19], and most pullout test researchers advise $1 \mathrm{~mm} / \mathrm{min}$. Farrag [20] obtained a similar test result at the pullout speed no faster than $6 \mathrm{~mm} / \mathrm{min}$ and specifies a displacement of 1 to $2 \mathrm{~mm} / \mathrm{min}$ for the reference speed. Meanwhile, ASTM D6706 [3] specifies that force increases shall not be greater than $2 \mathrm{kN} / \mathrm{m} / \mathrm{min}$.

As described above, there is required a pullout apparatus and test method for obtaining more feasible pullout parameters. Therefore, a multilayer spreading pullout apparatus is developed in this study, which suggests a multilayer spreading pullout test using the manufactured pullout apparatus. In this study, two types of reinforcements of which the shapes and characteristics are very different were used to carry out a multilayer spreading pullout test. The result of the experiment reveals applicability of the multilayer spreading pullout apparatus and the test method to determine feasible pullout parameters in designing a reinforced earth structure.

\section{Theoretical Consideration of Pullout Test}

2.1. Pullout Apparatus. A pullout apparatus is composed of four components of a soil box, a loading apparatus, a geosynthetics fixing device, and a pullout system (load cell). One of the major impact factors of pullout behaviors between the earth and the reinforcements is the pullout apparatus. Many researchers suggest that pullout characteristics depend on apparatus characteristics, components, and pullout box size. Therefore, pullout apparatuses of different sizes have been studied to address this issue. Exemplary impact factors on pullout parameters include pullout box size, length and the shape of used geosynthetics, and interference impact between members. The pullout apparatus is composed of a pullout box, a surcharge load apparatus (air bag), a pullout load apparatus, and measuring instruments. Consideration is taken into the indoor pullout test and studies carried out thus far.

The pullout test does not have any established standard test procedure to evaluate characteristics of pullout friction. The reason for no established standard test procedure is lack of reliability on pullout test results due to various impact factors, some examples being test procedures, compaction, box size, and tests.

Table 1 illustrates pullout apparatuses which have been used to examine pullout and shear characteristics between earth and reinforcements. Pullout apparatuses of different sizes have been manufactured to examine friction between the earth and reinforcements, a fundamental concept of reinforced earth.

It is essential to evaluate characteristics of friction between reinforcements and their surrounding earth before designing and analyzing reinforced earth structures. Exemplary methods include the direct shear test and pullout test. The characteristics of friction shown in the reinforcements of a reinforced earth structure include friction resistance of the reinforcements parallel to the direction of earth transformation and manual resistance by a support member and earth.

In general, the direct shear test is applied as a method of examining surface friction resistance and applies to a material for which the upper layer of earth surrounding the reinforcements is completely separated from its bottom layer. Meanwhile, the pullout test applies as a method of examining surface friction resistance and manual resistance to a reinforcement for which the top layer of earth surrounding them continues to contact its bottom layer.

2.2. Theoretical Consideration of Pullout Test. For the pullout test, various pullout apparatuses have been developed, and the following research results have also been made available. However, the pullout test involves some issues. That is, one of them is unevenly distributed pullout and tensile strength occurring in reinforcements when pullout forces are exerted. The pullout forces are divided by the area to obtain pullout stress, and it is difficult to determine an accurate area. Furthermore, a pullout apparatus is not an apparatus for applying loads to elements to destroy them and obtain strength parameters and is instead rather similar to a model experiment. Therefore, some research reveals that the result thereof is different where the size of pullout apparatuses varies. Since it is a large-scale test, test errors may be likely to occur due to different impact factors.

Therefore, a method widely employed is to obtain shear strength parameters for used earth and obtain pullout strength parameters of reinforced earth to multiply any coefficient in consideration of reinforcement shapes or characteristics. Nevertheless, a dominant opinion is still that a pullout apparatus should be used to find pullout parameters.

A pullout apparatus is specified in ASTM (2010) and GRI (2008), and its average normal size is 30 to $50 \mathrm{~cm}$ in breadth, $30 \mathrm{~cm}$ in height, and 60 to $100 \mathrm{~cm}$ in length. In particular, spreading length depends on pullout apparatus size, and the magnitude of pullout parameters depends on extensibility of reinforcements.

Table 2 illustrates pullout box size, characteristics of used samples, methods of manufacturing samples, and surcharge loads in previous studies on pullout test. Pullout apparatus size refers to breadth, height, and length thereof, and the most impact occurs on the length of a pullout soil box.

Table 2 illustrates various lengths of pullout boxes, between $600 \mathrm{~mm}$ and $3230 \mathrm{~mm}$. Although a pullout box is $1.0 \mathrm{~m}$ in length, most pullout forces are given to the front. It is thus preferred to measure pullout displacement occurring in the reinforcements to determine pullout parameters depending on pullout length for a soft geosynthetics pullout test. In conclusion, a very important item in determining feasible pullout parameters is to determine specifications of a pullout 
TABLE 1: Pullout test using pullout boxes of different size [21].

\begin{tabular}{|c|c|c|c|}
\hline Researcher & Year & $\begin{array}{c}\text { Pullout box size } \\
\text { (length } \times \text { width } \times \text { height })\end{array}$ & Remarks \\
\hline \multirow{2}{*}{ Palmeira and Milligan } & \multirow{2}{*}{1989} & $100 \mathrm{~cm} \times 100 \mathrm{~cm} \times 100 \mathrm{~cm}$ & Large \\
\hline & & $25 \mathrm{~cm} \times 15 \mathrm{~cm} \times 50 \mathrm{~cm}$ & Small \\
\hline Dennes T. Bergado & 1992 & $80 \mathrm{~cm} \times 130 \mathrm{~cm} \times 50 \mathrm{~cm}$ & \\
\hline Fannin and Raju & 1993 & $130 \mathrm{~cm} \times 64 \mathrm{~cm} \times 60 \mathrm{~cm}$ & \\
\hline Farrag & 1993 & $152 \mathrm{~cm} \times 90 \mathrm{~cm} \times 76 \mathrm{~cm}$ & \\
\hline Wilson-Fahmy & 1994 & $190 \mathrm{~cm} \times 91 \mathrm{~cm} \times 110 \mathrm{~cm}$ & \\
\hline Cho and Kim & 1995 & $140 \mathrm{~cm} \times 60 \mathrm{~cm} \times 60 \mathrm{~cm}$ & \\
\hline Abramento and Whittle & 1995 & $68 \mathrm{~cm} \times 30 \mathrm{~cm} \times 62.5 \mathrm{~cm}$ & \\
\hline Alfaro and & & & \\
\hline $\begin{array}{l}\text { Hayashi and Miura } \\
\text { and Watanabe }\end{array}$ & 1995 & $150 \mathrm{~cm} \times 60 \mathrm{~cm} \times 40 \mathrm{~cm}$ & \\
\hline Ghosh and Bhasim & 1996 & $50 \mathrm{~cm} \times 30 \mathrm{~cm} \times 30 \mathrm{~cm}$ & \\
\hline Ochiai & 1996 & $60 \mathrm{~cm} \times 40 \mathrm{~cm} \times 20 \mathrm{~cm}$ & \\
\hline Sabit Adanur & 1996 & $91 \mathrm{~cm} \times 61 \mathrm{~cm} \times 46 \mathrm{~cm}$ & \\
\hline Yei-Sain Lee & 1996 & $60 \mathrm{~cm} \times 35 \mathrm{~cm} \times 24 \mathrm{~cm}$ & \\
\hline Lopes and Ladeira & 1996 & $153 \mathrm{~cm} \times 100 \mathrm{~cm} \times 80 \mathrm{~cm}$ & \\
\hline Shin & 1999 & $60 \mathrm{~cm} \times 40 \mathrm{~cm} \times 100 \mathrm{~cm}$ & \\
\hline $\begin{array}{l}\text { Teixeira, Bueno and } \\
\text { Zornberg }\end{array}$ & 1999 & $150 \mathrm{~cm} \times 70 \mathrm{~cm} \times 48 \mathrm{~cm}$ & \\
\hline Ghionna. V. N. & 2001 & $150 \mathrm{~cm} \times 60 \mathrm{~cm} \times 70 \mathrm{~cm}$ & \\
\hline Bang. Y. G & 2001 & $60 \mathrm{~cm} \times 60 \mathrm{~cm} \times 30 \mathrm{~cm}$ & \\
\hline S. A. Aiban and S. M. Ali & 2001 & $50 \mathrm{~cm} \times 10 \mathrm{~cm} \times 25 \mathrm{~cm}$ & \\
\hline $\begin{array}{l}\text { Yuan Z. and J. K. Moore } \\
\text { and R. H. Swan }\end{array}$ & 2002 & $150 \mathrm{~cm} \times 60 \mathrm{~cm} \times 30 \mathrm{~cm}$ & \\
\hline Nejad and Small & 2005 & $30 \mathrm{~cm} \times 26.5 \mathrm{~cm} \times 37 \mathrm{~cm}$ & \\
\hline $\begin{array}{l}\text { Abdelrahman, Ashmawy } \\
\text { and Abdelmoniem }\end{array}$ & 2007 & $120 \mathrm{~cm} \times 70 \mathrm{~cm} \times 116 \mathrm{~cm}$ & \\
\hline Hossain and Sakai & 2007 & $15 \mathrm{~cm} \times 10 \mathrm{~cm} \times 10 \mathrm{~cm}$ & \multirow{3}{*}{$\begin{array}{l}\text { Minimum } \\
\text { standard }\end{array}$} \\
\hline \multirow{2}{*}{ ASTM } & 2001 & $61 \mathrm{~cm} \times 41 \mathrm{~cm} \times 30 \mathrm{~cm}$ & \\
\hline & 2003 & $61 \mathrm{~cm} \times 46 \mathrm{~cm} \times 30.5 \mathrm{~cm}$ & \\
\hline GRI & 1991 & $120 \mathrm{~cm} \times 75 \mathrm{~cm} \times 60 \mathrm{~cm}$ & $\begin{array}{c}\text { Minimum } \\
\text { standard }\end{array}$ \\
\hline Kim, J. H & 2016 & $100 \mathrm{~cm} \times 40 \mathrm{~cm} \times 90 \mathrm{~cm}$ & This study \\
\hline
\end{tabular}

soil box ideally sized without a difference between the total area method and the effective area method.

Most prior studies on characteristics of reinforced earth friction are about direct shear tests and pullout tests depending on reinforcement types and earth characteristics. Furthermore, sand is usually used in a pullout test, as shown in Table 6, to gather experiment data and evaluations of the characteristics of reinforced earth friction. That is to say, researchers continue to study characteristics of different geogrids and pullout characteristics depending on various used earth materials.

Although the importance of tensile strength has been discussed while emphasizing the role of geogrids in reinforced earth, it is necessary to further study the method of the pullout test and the parameters of reinforced earth. The pullout parameters are actually very important in designing a reinforced earth structure to implement practical design. It is essential to find out the interaction mechanism between the earth and reinforcements to determine pullout parameters for designing a reinforced earth structure in order to develop many geosynthetics products, earth in gradually wider ranges and application programs.

Ingold [9] reported that the maximum angle of friction decreases while the surcharge load increases from the pullout test result about full-scale reinforced earth retaining walls and also reported that the vertical stress with angles of low friction at an interface between earth and geosynthetics is greater than the coefficient of earth friction.

Moreover, Ochiai et al. [24] suggested application of the total area method under low confining stress for site application. Koutsourais et al. [25] evaluated that pullout resistance values are approximately $13 \%$ to $17 \%$ higher than 
TABLE 2: Summary of pullout test apparatus and characteristics of materials [22].

\begin{tabular}{|c|c|c|c|c|c|}
\hline \multirow[b]{2}{*}{ Reference } & \multirow[b]{2}{*}{$\begin{array}{l}\text { Box dimensions } \\
(\mathrm{mm})\end{array}$} & \multicolumn{2}{|c|}{ Soil characteristics } & \multirow[b]{2}{*}{$\begin{array}{c}\text { Soil } \\
\text { preparation }\end{array}$} & \multirow[b]{2}{*}{$\begin{array}{l}\text { Surcharge } \\
\quad(\mathrm{kPa})\end{array}$} \\
\hline & & Soil type & $\begin{array}{c}C(\mathrm{kPa})-\varphi\left({ }^{\circ}\right) \\
\text { grain size }(\mathrm{mm})\end{array}$ & & \\
\hline $\begin{array}{l}\text { Bonczkewicz \& Christopher } \\
\text { (1987) }\end{array}$ & $1325 \times 675 \times 150$ & Sand-silt & $\begin{array}{l}\varphi=35-43 \\
P I=6-21\end{array}$ & Vibrator & $35-70-100$ \\
\hline Ochiai \& Otani (1992) & $600 \times 400 \times 400$ & Sand & $\varphi=36$ & Pluviation & $25-50-75$ \\
\hline Collin \& Berg (1993) & $2100 \times 900 \times 500$ & Sand-SP & $\varphi=28$ & Compaction & $49-100$ \\
\hline Yasuda \& Marui (1993) & $500 \times 300 \times 100$ & Volcanic ash & $\begin{array}{l}\varphi=28-36 \\
\text { Dr }=30 \%\end{array}$ & Compaction & $20-100$ \\
\hline Farrag \& Griffin (1993) & $1500 \times 900 \times 760$ & Clay & $\mathrm{PI}=24$ & Vibrator & 48.2 \\
\hline Razaqpur \& Bauer (1993) & $1040 \times 230 \times 380$ & Crushed stone & $\begin{array}{c}\varphi=36-40 \\
D_{50}=8 \mathrm{~mm}\end{array}$ & Compaction & $14-20$ \\
\hline Wilson-Fahmy \& Koerner (1993) & $1900 \times 9100 \times 110$ & Sand & $\begin{array}{c}\varphi=49 \\
\mathrm{D}_{50}=0.7 \mathrm{~mm}\end{array}$ & Compaction & $\begin{array}{l}10-25 \\
51-100\end{array}$ \\
\hline Alfaro \& Bergado (1995) & $3230 \times 700 \times 700$ & Gravel-GW & $\varphi=41-45$ & Compaction & $20-30-50$ \\
\hline Lechshinsky \& Kaliakin (1995) & $600 \times 200 \times 300$ & Ottawa sand & $\begin{aligned} \varphi & =40 \\
\mathrm{D}_{50} & =0.25\end{aligned}$ & Pluviation & $\begin{array}{l}17.2-34.2 \\
51-70-100\end{array}$ \\
\hline Raju \& Fannin (1998) & $3230 \times 700 \times 700$ & Sand & $\begin{array}{c}\varphi=36 \\
\mathrm{D}_{50}=0.9\end{array}$ & Compaction & $4-20$ \\
\hline Lopes \& Lopes (1999) & $1530 \times 1000 \times 800$ & Sand-gravel & $\begin{array}{c}\varphi=40 \\
\mathrm{D}_{50}=1.2 \mathrm{~mm}\end{array}$ & Compaction & $50-100-200$ \\
\hline Bolt \& Duzynska (2000) & $1600 \times 600 \times 360$ & Quartz & $\varphi=28-36$ & Compaction & $25-50-100$ \\
\hline Sugimoto \& Alagiawanna (2003) & $680 \times 300 \times 625$ & Sand & $\begin{aligned} \varphi & =30 \\
\mathrm{D}_{50} & =0.34\end{aligned}$ & Pluviation & $5-49-93$ \\
\hline Nernheim \& Meyer (2003) & $1500 \times 600 \times 700$ & Sand-SP & $\varphi=30-43$ & Pluviation & $30-45-60$ \\
\hline Moraci \&Recalcati (2004) & $1700 \times 600 \times 680$ & Sand-SP & $\begin{array}{l}\varphi=42-48 \\
D_{50}=1.20\end{array}$ & Compaction & $\begin{array}{c}10-25 \\
50-100\end{array}$ \\
\hline Fakharian \& Nayeri (2007) & $1200 \times 600 \times 600$ & Silica sand & $\begin{array}{l}\varphi=34-40 \\
D_{50}=1.20\end{array}$ & Pluviation & $\begin{array}{c}15-25 \\
50-100\end{array}$ \\
\hline
\end{tabular}

the internal friction of earth at low confining pressure $(<4$ psi), and a similar tendency is also observed at a higher confining pressure.

As described above, confining stress has a great impact on pullout tests. Dilatancy affecting friction will be greater at low stress than at high stress considering that dilatancy is dependent on the scale of confining loads acting on reinforcements. As a result, since the pullout parameter is different depending on the magnitude of confining stress, the confining load condition that enables pullout characteristics between earth and reinforcements needs to be fully developed.

\section{Developing Multilayer Spreading Pullout Test Apparatus and Method of Pullout Test}

3.1. Multilayer Spreading Pullout Apparatus. In this study, the multistage spreading pullout apparatus was used, in which the pullout system is composed of three stages as shown in Figures 1 and 2 . The pullout test was carried out with various types of reinforcements to examine pullout characteristics of reinforced earth from the pullout apparatus, that is, interbehavior characteristics between earth and reinforcements in pullout.

The loading apparatus manufactured for and used in the pullout test was an air pressure type. As shown in Table 1,

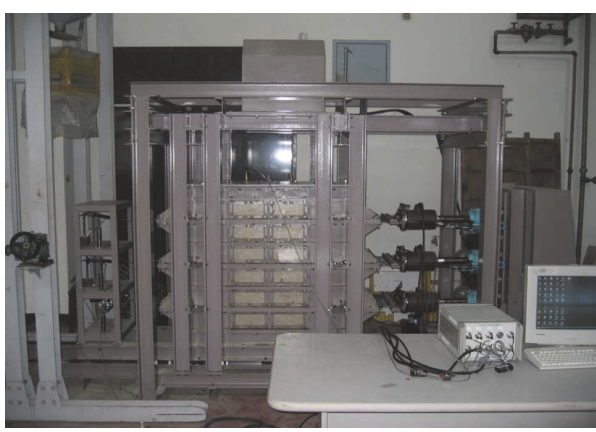

FIGURE 1: Multilayer pullout test apparatus [21].

many test devises have been manufactured to verify the pullout parameters. Some organizations such as Geosynthetic Research Institute, Japanese Geotechnical Society, and ASTM suggested the size of the experimental apparatus. According to these studies, our study has developed the pullout box in which the pullout box was sized to be $H \times L \times B$ of $40 \mathrm{~cm}$, $90 \mathrm{~cm}$, and $100 \mathrm{~cm}$, respectively. For lateral wall displacement of the soil box, allowable limit is $45 \mathrm{~cm}$. The soil box is divided into upper, center, and bottom parts, and depth thereof is $30 \mathrm{~cm}$, respectively. This size was to remove the influence 


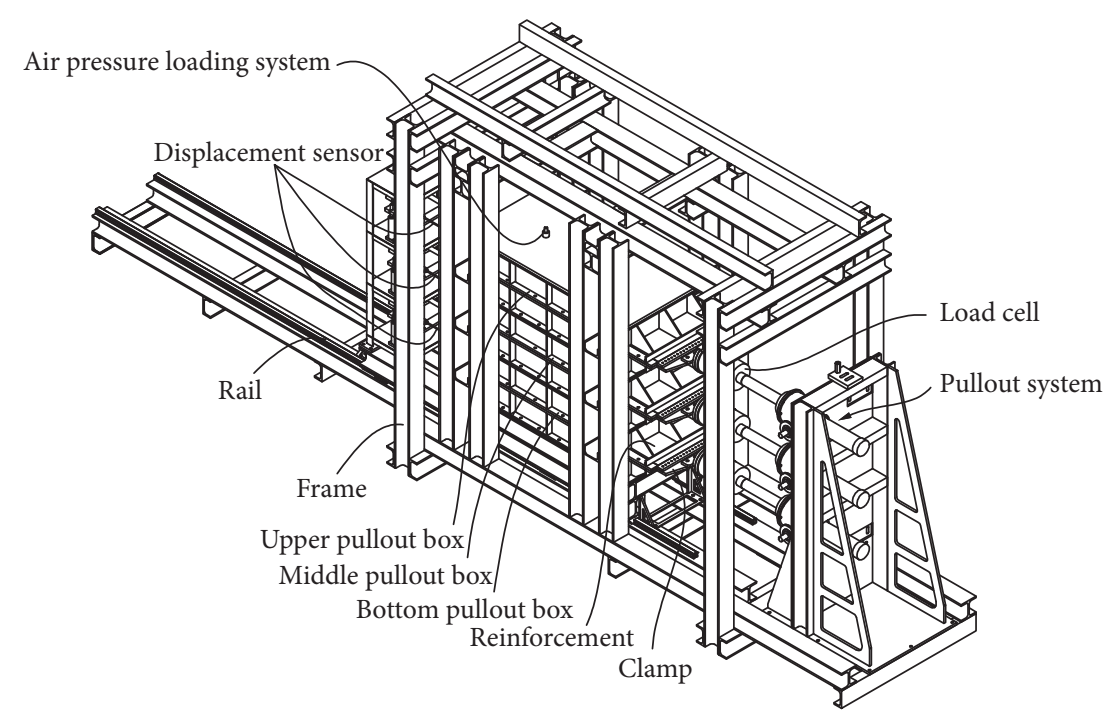

FIGURE 2: Detailed drawing of the multilayer pullout test apparatus [21].

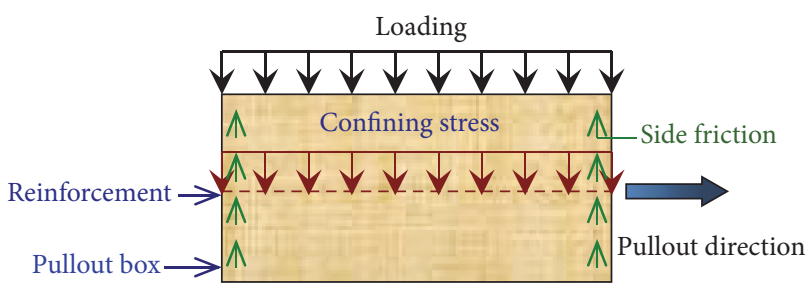

(a) Single layer

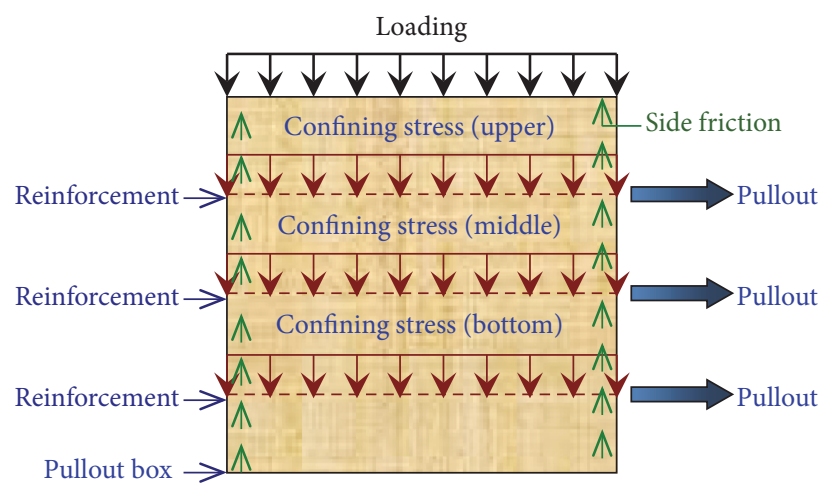

(b) Multilayer

Figure 3: Pullout test.

of the size effect of the pullout test. On top of the upper soil box, an air pressure loading system (air pressure bag system) is installed to give a uniform confining load to the inside of the soil box by means of air pressure. Maximum air pressure given to the air pressure loading system is $200 \mathrm{kPa}$. The geosynthetics fixing device is fixed by tightening screws and directly connected to the load cell to obtain data.

3.2. Suggesting Method of Multilayer Spreading Pullout Test. For a conventional pullout test, a test apparatus composed of a single pullout box is used to examine characteristics of friction between earth and geosynthetics. The test is normally carried out at least three times with different confining loads.

As shown in Figure 3(a), the soil box in the reinforced earth pullout apparatus is normally composed of one stage. After taking the earth in the soil box when one test process finishes, earth and the reinforcement are set again to form a ground model and carry out pullout test with different confining loads. Though the pullout test is carried out three times or so, an average pullout force between earth and the reinforcement is calculated depending on confining load conditions, and pullout parameters are calculated from the relation between the confining stress and the average pullout resistance force. In this case, it is essential to manufacture the ground model at least three times depending on test conditions.

The multilayer spreading pullout test enables multilayer reinforcements to be spread and to manufacture and test a ground model once, that is, to examine behavior characteristics between earth and reinforcements through simultaneous and sequential pullout of the reinforcements. It also implements calculation of accurate pullout parameters by addressing changes in ground engineering properties of a ground model, the greatest cause of errors of test results.

Since the multilayer spreading pullout test is carried out from the upper stage and then goes to the bottom stage, disturbances in the lower stage ground may be avoided in testing the upper stage. Furthermore, the side friction resistance was reduced by mixing grease with oil to paste the mixture on the wall and cover it with a plastic film. It was determined from the test result that wall friction resistance still remaining is cancelled by the dead weight of the ground. The conventional 
TABLE 3: Physical properties of Jumunjin standard sand.

\begin{tabular}{|c|c|c|c|c|c|c|}
\hline \multirow[b]{2}{*}{ Types of soil } & \multicolumn{5}{|c|}{ Physical property } & \multirow[b]{2}{*}{$\begin{array}{c}\text { Relative } \\
\text { density } \\
(\%)\end{array}$} \\
\hline & $\begin{array}{c}\text { Specific } \\
\text { gravity } \\
G_{S}\end{array}$ & $\begin{array}{c}\text { Water } \\
\text { content } \\
(\%)\end{array}$ & $\begin{array}{c}\text { Maximum } \\
\text { dry density } \\
\left(\mathrm{g} / \mathrm{cm}^{3}\right)\end{array}$ & $\begin{array}{c}\text { Minimum } \\
\text { dry density } \\
\left(\mathrm{g} / \mathrm{cm}^{3}\right)\end{array}$ & $\begin{array}{c}\text { Density of } \\
\text { ground } \\
\text { model } \\
\left(\mathrm{g} / \mathrm{cm}^{3}\right)\end{array}$ & \\
\hline $\begin{array}{l}\text { Jumunjin } \\
\text { standard } \\
\text { sand }\end{array}$ & 2.67 & 0.2 & 1.606 & 1.358 & 1.550 & 80 \\
\hline
\end{tabular}

TABLE 4: Physical properties of reinforcements used for testing.

\begin{tabular}{lccc}
\hline Types of reinforcement & Maximum tensile strength $(\mathrm{kN} / \mathrm{m})$ & Maximum tensile strain $(\%)$ & Size $(\mathrm{mm})$ \\
\hline Type-A & 100.0 & 6.8 & Grid $40 \times 40$ \\
Type-B & 105.2 & 11.1 & Figure 4 \\
\hline
\end{tabular}

one-stage test apparatus may be more effective for accurate test. However, since it requires much labor, homogeneity between the ground models manufactured first and later may be significantly deteriorated where the ground models are manufactured by means of the one-stage test apparatus at least three times. In other words, there is a possibility of even lower accuracy of the test because of apparatus user's fatigue.

Meanwhile, it is determined that the apparatus developed in this study may easily ensure ground homogeneity because the ground model is manufactured just once, and apparatus user's fatigue is even reduced in comparison with conventional one-stage apparatuses because continuous testing is implemented without a great time difference. That is, the apparatus suggested in this study implements pullout test within a short time even more easily.

As shown in Figure 3(b), the method of multilayer spreading pullout test is carried out systematically by spreading reinforcements on the bottom stage, the middle stage and the upper stage of the pullout box with different confining loads, respectively, and the sequence of pullout test is described below.

(1) Predetermine the magnitude of vertical loads used in the pullout test. In the pullout test carried out in this study, the vertical loads were three types of 30,60 , and $90 \mathrm{kPa}$.

(2) The pullout soil box divided is composed of three soil boxes of an upper stage, a middle stage, and a bottom stage. Spread reinforcements from the bottom soil box after manufacturing a ground model depending on relative density.

(3) Repeat the process of (2) for the middle stage and the upper stage. Secure the pullout soil boxes in the middle and the upper stages to avoid the upper and bottom soil boxes not to be spaced, and smooth the ground surface for uniform loading.

(4) Install the air pressure loading system on top of the upper soil box after manufacturing the ground model.

(5) Connect the spread reinforcements to the clamp, and couple just the upper part when connecting the reinforcements. Carry out pullout from the upper part depending on required confining loads.

(6) Repeat the pullout process of (5) for the middle and the bottom parts. Be sure to connect the reinforcements to the clamp securely in each step.

(7) Completely remove confining loads after finishing the pullout test for the upper and the middle parts. Removing applied confining loads contributes to gradually decreasing pullout resistance developed between earth and the reinforcements, finally stabilizing the ground, and also making pullout resistance close to zero (0). Completely removing confining loads is intended to maximize decreasing the interference effect by the multilayer spreading pullout test.

(8) Measure the front pullout displacement, the pullout force, and the displacement at nodes in the pullout process.

(9) Determine the pullout parameters according to the method of evaluation from the relation curve of the pullout force relative to the pullout displacement depending on respective confining loads.

\section{Test Conditions and Method}

4.1. Jumunjin Standard Sand and Characteristics of Reinforcement. Jumunjin standard sand was used as a sample to manufacture a ground model, and Table 3 illustrates physical properties of Jumunjin standard sand. It corresponds to SP in the Unified Soil Classification System, and the angle of internal friction is $34.5^{\circ}$. Table 4 illustrates physical properties of geosynthetics used in pullout test.

4.2. Experiment Conditions and Method. The method of manufacturing a ground model is very different depending on its use. A multiple sieving pluviation apparatus was used to reproduce the relative density required for the standard sand. Figure 6 shows schematically the multiple sieving pluviation apparatus used in this test.

The condition of using the multiple sieving pluviation apparatus to reproduce the relative density of $80 \%$ is $5.0 \mathrm{~mm}$ 


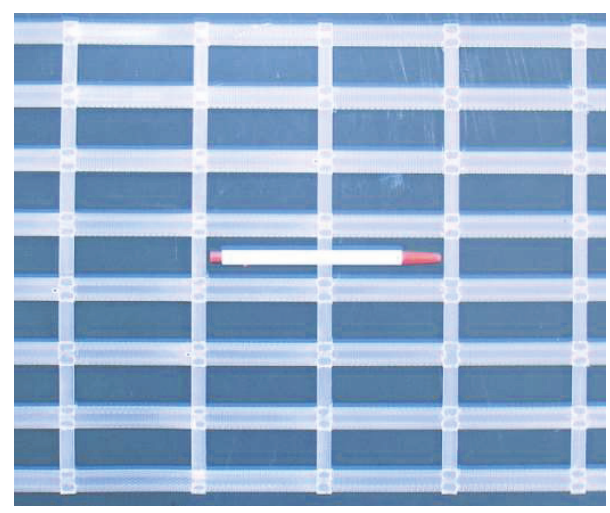

Figure 4: Totogrid.

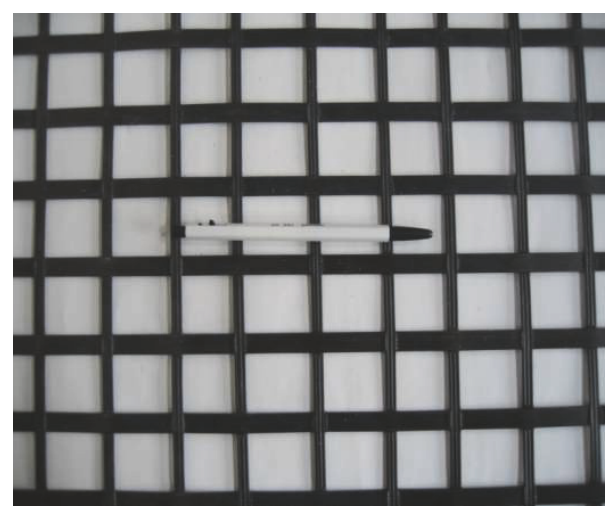

FIGURE 5: Fortrac geogrid.

in sieve pore size, 5 sieve layers, $3.0 \mathrm{~cm}$ in discharge hole diameter, and $70 \mathrm{~cm}$ in drop height. Pullout speed in the pullout test was a constant of $1 \mathrm{~mm} / \mathrm{min}$, and the pullout force was measured by the load cell connected to the geosynthetics fixing device. Figure 7 shows the systematic pullout sequence of upper stage, middle stage, and bottom stage for the pullout test.

The multistage spreading pullout apparatus is manufactured to perform the same function as conventional pullout apparatuses where the bottom stage of the pullout soil box is just used. Therefore, the test condition for obtaining feasible pullout parameters is to carry out both the single-layer pullout test and the multistage spreading pullout test.

Table 5 illustrates test conditions for different types of reinforcements. The confining stress $\left(\sigma_{y}\right)$ in the test conditions is $30 \mathrm{kPa}, 60 \mathrm{kPa}$, and $90 \mathrm{kPa}$ different depending on reinforcements, to carry out pullout test for the standard sand ground, respectively. For the pullout test, the standard sand was manufactured with a relative density of $80 \%$ in the ground model.

\section{Verifying Method of Multilayer Spreading Pullout Test}

The single-layer and multilayer spreading pullout test results were compared and reviewed for the standard sand ground

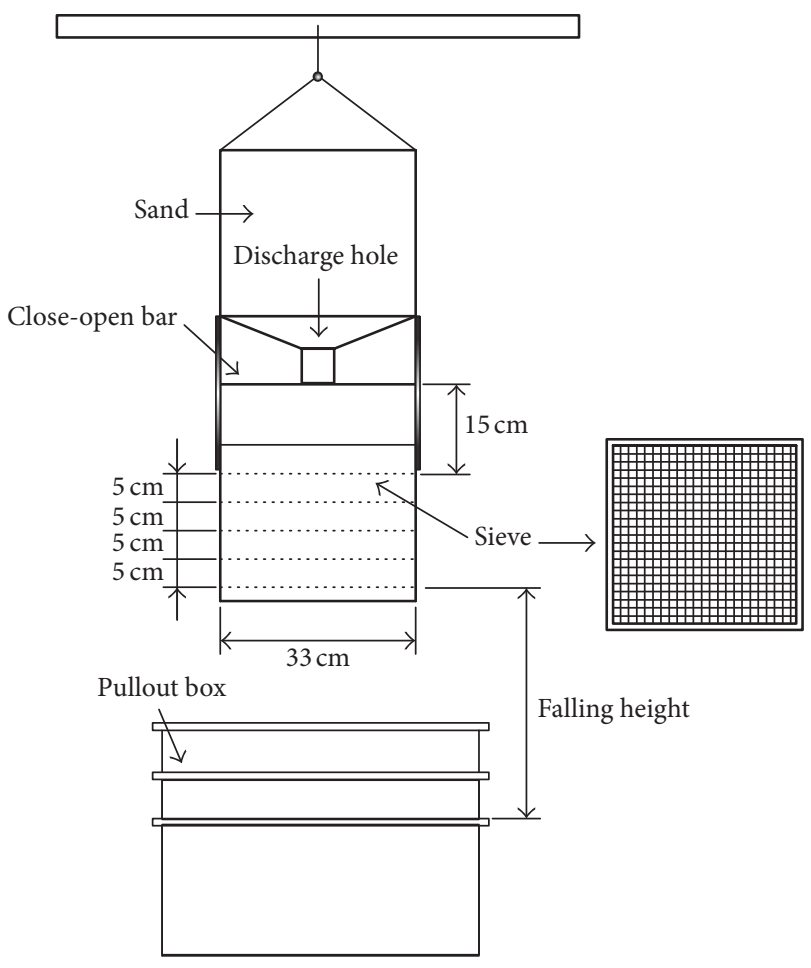

FIgURE 6: Multiple sieving pluviation apparatus [23].

in order to verify the method of multilayer spreading pullout test.

5.1. Type-A Soft Geogrid. Figure 8 shows front pullout displacement relative to pullout forces obtained from the singlelayer test and the multilayer spreading pullout test using the Type-A reinforcement. Figure 8 shows pullout curves with confining stress of 30,60 , and $90 \mathrm{kPa}$, respectively, obtained from the result of single-layer and multilayer spreading pullout tests.

The pullout force also increases as front pullout displacement and confining stress increase in the single-layer pullout test as they do in the multilayer spreading pullout test. In particular, although the pullout force is approximately $30 \mathrm{kN} / \mathrm{m}$ with confining stress of $30 \mathrm{kPa}$, the pullout force significantly increased more than twofold when the confining stress had an increase to be $90 \mathrm{kPa}$. This implies that confining stress is a main impact factor affecting the pullout test result.

Meanwhile, when confining stress increased to be $90 \mathrm{kPa}$, it is determined that the Type-A reinforcement, soft geogrid, experienced tensile fractures in the geogrid itself, rather than pullout fractures in which shear transformation occurs in its total area. As a result, it is ideal to control test conditions, for example, controlling small confining stress conditions and spreading length that may cause shear transformation in total area of the geosynthetics.

In the standard sand ground described above, as the front pullout displacement increases, the pullout force linearly increases up to $40 \mathrm{~mm}$ but converges with no more increase in pullout forces due to particle rearrangement following reinforcement pullout. 
TABLE 5: Conditions of pullout test.

\begin{tabular}{|c|c|c|c|}
\hline Test number & Test & Reinforcement & $\begin{array}{c}\text { Confining stress } \\
\sigma_{v}(\mathrm{kPa}) \\
\end{array}$ \\
\hline FST-1 ${ }^{* 1}$ & \multirow{3}{*}{ Single-layer } & \multirow{3}{*}{ Type-A } & 30 \\
\hline FST-2 & & & 60 \\
\hline FST-3 & & & 90 \\
\hline FST-4 & Multilayer & Type-A & $30,60,90$ \\
\hline TST- $5^{* 2}$ & \multirow{3}{*}{ Single-layer } & \multirow{3}{*}{ Type-B } & 30 \\
\hline TST-6 & & & 60 \\
\hline TST-7 & & & 90 \\
\hline TST-8 & Multilayer & Type-B & $30,60,90$ \\
\hline
\end{tabular}

${ }^{* 1}$ FST: Fortrac Sand Test, ${ }^{* 2}$ TST: Totogrid Sand Test.

TABLE 6: Pullout parameters according to pullout test in sand.

\begin{tabular}{|c|c|c|c|c|}
\hline \multirow{2}{*}{ Pullout paramete rs } & \multicolumn{2}{|c|}{ Type-A } & \multicolumn{2}{|c|}{ Type-B } \\
\hline & Single-layer & Multilayer & Single-layer & Multilayer \\
\hline Pullout friction angle $\varphi_{p}\left({ }^{\circ}\right)$ & 24.37 & 23.51 & 18.47 & 17.17 \\
\hline
\end{tabular}

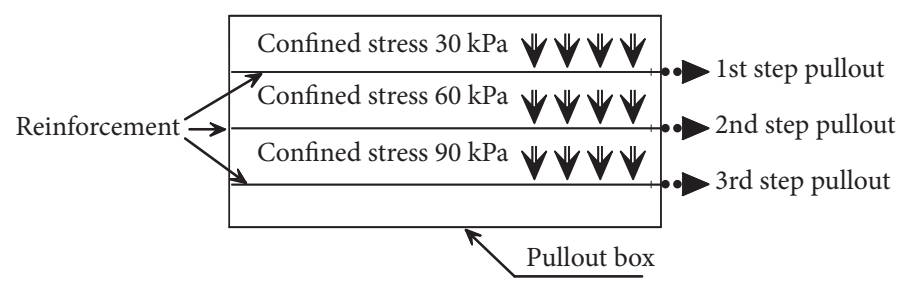

FIGURE 7: Schematics of the pullout test condition.

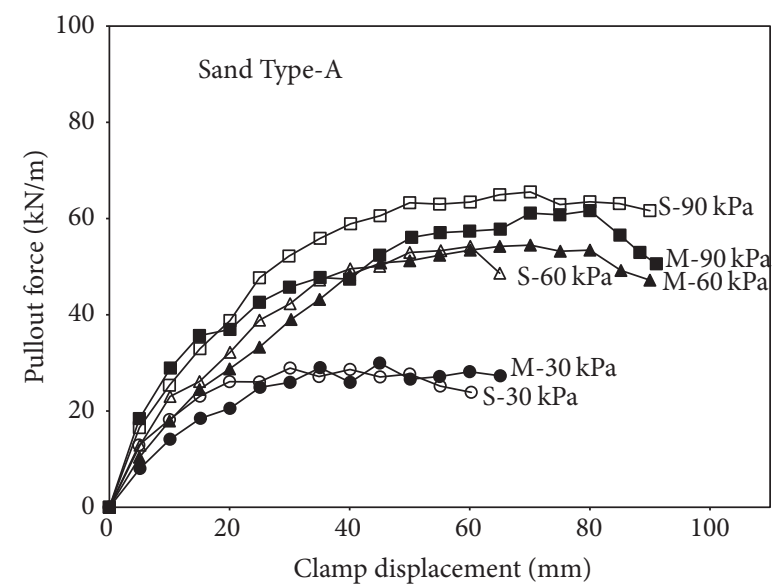

FIGURE 8: Front pullout displacement relative to pullout force with confining stress using Type-A.

5.2. Type-B Stiff Geogrid. Figure 9 shows front pullout displacement relative to pullout forces obtained from the result of single-layer pullout test using Type-B stiff geogrid reinforcements. Figure 9 shows pullout curves depending on respective confining stress of 30,60 , and $90 \mathrm{kPa}$ from the result of single-layer pullout test. Although the results of

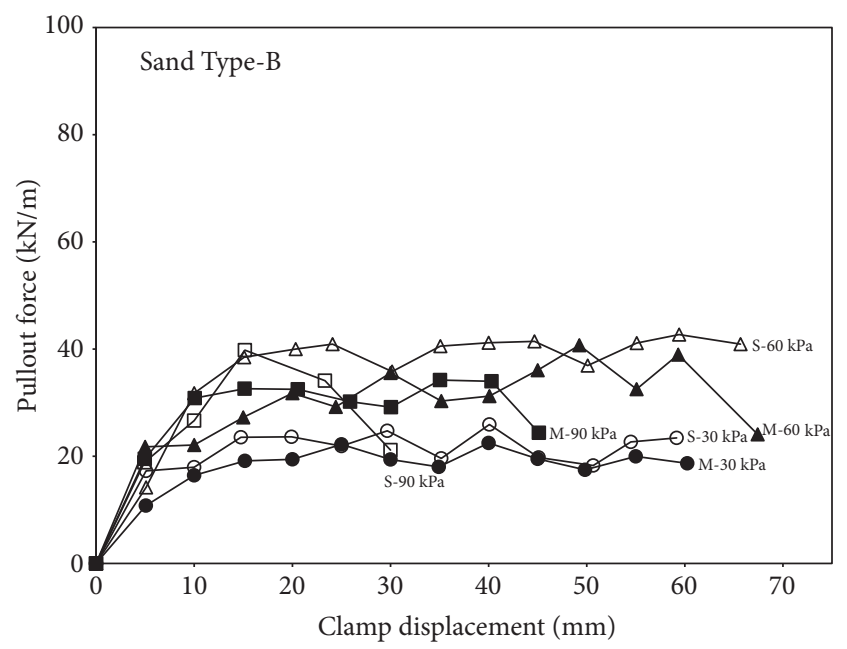

FIGURE 9: Front pullout displacement relative to pullout force with confining stress using Type-B.

the two tests are slightly different, they are almost similarly derived. Where confining stress was $90 \mathrm{kPa}$ in the singlelayer pullout test, breaking occurred when pullout displacement of approximately $18 \mathrm{~mm}$ occurred. In the multilayer spreading pullout test, the point of rapidly dropping pullout 


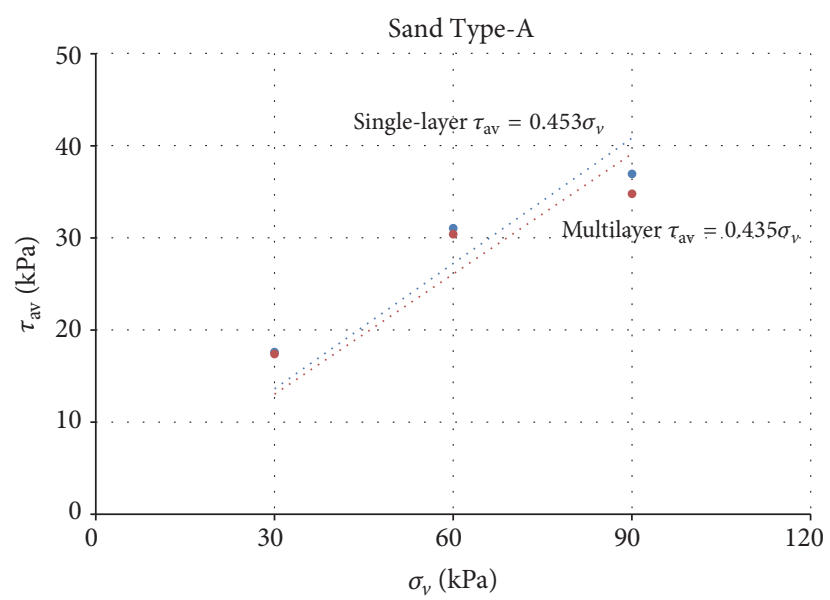

FIGURE 10: Relation curve for confining stress relative to pullout friction stress of Type-A reinforcement.

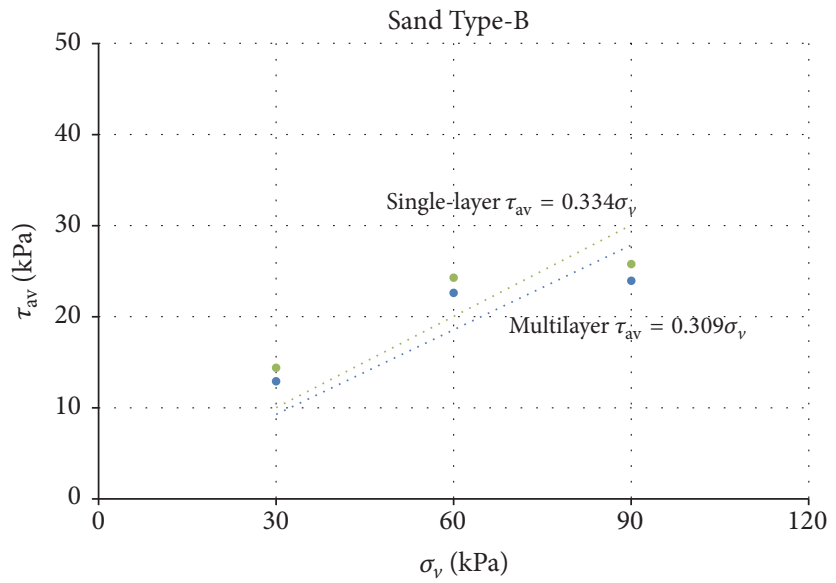

FIGURE 11: Relation curve of confining stress relative to pullout friction stress of Type-B reinforcement.

force is when pullout displacement of approximately $20 \mathrm{~mm}$ occurred, implying a similar tendency. The breaking of the reinforcement occurred at the contact point, and the analysis of the pullout parameters was based on the greatest pullout force before the breaking.

It was shown that the Type-B stiff geogrid experienced great changes in pullout forces following pullout displacement like up-and-down wobbly movement, and the changes are considered to occur because of the great space between grids and a projection in the intersection.

When pullout forces are applied to the front of stiff geogrid spread in the soil box, the resistance due to friction between the standard sand and the length direction member of the reinforcement, and the manual resistance in the lateral direction member perpendicular to the resistance simultaneously occur. Observation of the reinforcements after pullout test revealed that the pullout force decreased because of transformation, damage, and breaking of most reinforcement junctions. Therefore, since reinforcements, for example, Type-B reinforcements, may experience pullout forces resulting from characteristics of the junctions, it should be ideally considered in designing them.
5.3. Comparison and Evaluation of Pullout Parameters. Average pullout stress is obtained by using the total area method. The gradient of the straight line in the relation curves corresponds to the angle of pullout friction $\left(\varphi_{p}\right)$, and the intercept value corresponds to the pullout cohesion force (cp). In particular, in the standard sand ground, since the pullout cohesion force is zero (0), the angles of pullout friction were just analyzed. Figures 10 and 11 show average pullout stress relative to confining stress when using Type-A and Type-B reinforcements, respectively. The angles of pullout friction may be calculated from the gradient of relation curves in the figures.

Table 6 illustrates the angles of pullout friction for respective reinforcements from the results of the single-layer pullout test and the multilayer spreading pullout test. Since the pullout cohesion force is zero (0) in the standard sand ground, the angles of pullout friction were just analyzed. With respect to the angles of pullout friction, the single-layer pullout test is $0.86^{\circ}$ and $1.30^{\circ}$ greater than the multilayer spreading pullout test for Type-A and Type-B, respectively, implying a very small difference. The difference of angles of pullout friction in the single-layer pullout test and the multilayer spreading 
pullout tests is $0.86^{\circ}$ to $1.30^{\circ}$ for Type-A and Type-B, which is within the test error range shown in the pullout test.

As a result, it is determined that pullout parameters obtained through the multilayer spreading pullout test are almost similar to those obtained through the single-layer pullout test for the Type-A and Type-B reinforcements. The pullout test result suggests that the multilayer spreading pullout test is the more efficient pullout test to obtain pullout parameters.

\section{Conclusion}

This study aims to develop a multilayer spreading pullout apparatus to obtain pullout parameters more efficiently and suggests a multilayer spreading pullout test using the developed apparatus. The multilayer spreading pullout test is verified by using two types: one type of stiff geogrid and the other type of soft geogrid popular typical reinforcements currently used. The result is summarized as follows.

(1) Develop a multilayer spreading pullout apparatus for determining more efficiently angles of pullout friction and pullout cohesion forces, that is, pullout parameters, developing between earth and reinforcements buried in earth when they are pulled out in a reinforced earth structure. A multilayer spreading pullout test which is an efficient pullout test is suggested. The strength of this test is that the pullout test may be carried out at least three times while changing the confining loads of one and the same ground model.

(2) In the curves of front pullout displacement relative to pullout forced for respective reinforcements in the multilayer spreading pullout test and the conventional pullout test, the relation curves schematically are similar although they are slightly different. This difference may be errors resulting from nonhomogeneity of the ground model and used reinforcements. In consideration of the error range occurring in a pullout test, the result of this test suggests a potential of using the multilayer spreading pullout apparatus as a new pullout apparatus.

(3) The difference between angles of pullout friction in Type-A and Type-B is 0.86 to $1.30^{\circ}$ obtained through comparison and review thereof, implying insignificant difference and an allowable error range of pullout test. It demonstrates that the multilayer spreading pullout apparatus and the multilayer spreading pullout test developed in this study are an apparatus and pullout test technique to obtain pullout parameters more efficiently.

(4) Many researchers have studied the method of examining characteristics of friction of reinforced earth, but there are still many difficulties in application of their results to site works. This led the researchers of this study to develop the multilayer spreading pullout test introduced in this paper to improve the result of prior studies. More studies on impact factors are required to calculate pullout parameters applicable to designing a method of reinforced earth structures in the future.

\section{Conflicts of Interest}

The authors declare that they have no conflicts of interest.

\section{References}

[1] E. M. Palmeira and G. W. E. Milligan, "Scale and other factors affecting the results of pull-out tests of grids buried in sand," Geotechnique, vol. 39, no. 3, pp. 511-524, 1989.

[2] D. T. Bergado and J.-C. Chai, "Pullout force/displacement relationship of extensible grid reinforcements," Geotextiles and Geomembranes, vol. 13, no. 5, pp. 295-316, 1994.

[3] ASTM Standard D6706, "Test for measuring geosynthetic pullout resistance in soil," in Annual Book of Standards, vol. 04.13, ASTM International, West Conshohoken, PA, USA, 2007.

[4] ASTM D5321, "Standard test for determining the coefficient of soil and geosynthetic or geosynthetic and geosynthetic friction by direct shear," ASTM International, 2008.

[5] ASTM D5321, "Standard method for determining the shear strength of Soil-Geosynthetic and geosynthetic- interfaces by direct shear," ASTM International, 2012.

[6] GRI Tests, “GRI GG5 Geogrid Pullout, GRI,” 1991.

[7] J. Bacot, M. Iltis, P. Lareal, T. Paumier, and G. Sanglerat, "Study of the soil reinforcement friction coefficient," in Proceedings of the ASCE Symposium on Earth Reinforcement, pp. 157-185, Pittsburgh, PA, USA, 1978.

[8] F. Scholsser and V. Elias, "Friction in reinforced earth," in Proceedings of the ASCE Symposium on Earth Reinforcement, vol. 17, pp. 735-762, Pittsburgh, PA, USA, 1978.

[9] T. S. Ingold, "Laboratory pull-out testing of grid reinforcements in sand," Geotechnical Testing Journal, vol. 6, no. 3, pp. 101-111, 1983.

[10] A. Sridharan, S. Murthy, B. R. Bindumadhava et al., "Technique for using fine-grained soil in reinforced earth," Journal of Geotechnical Engineering ASCE, vol. 117, no. 8, pp. 1174-1190, 1991.

[11] G. V. Rao and S. K. Pandey, "Evaluation of geotextile-soil friction," Geotechnique, vol. 18, pp. 77-105, 1988.

[12] R. J. Bathurst, B. Huang, and T. M. Allen, "Interpretation of laboratory creep testing for reliability-based analysis and load and resistance factor design (LRFD) calibration," Geosynthetics International, vol. 19, no. 1, pp. 39-53, 2012.

[13] L.-M. Chu and J.-H. Yin, "Comparison of interface shear strength of soil nails measured by both direct shear box tests and pullout tests," Journal of Geotechnical and Geoenvironmental Engineering, vol. 131, no. 9, pp. 1090-1097, 2005.

[14] F. M. Ezzein and R. J. Bathurst, "A new approach to evaluate soilgeosynthetic interaction using a novel pullout test apparatus and transparent granular soil," Geotextiles and Geomembranes, vol. 42, no. 3, pp. 246-255, 2014.

[15] Y. Miyata and R. J. Bathurst, "Reliability analysis of soil-geogrid pullout models in Japan," Soils and Foundations, vol. 52, no. 4, pp. 620-633, 2012.

[16] J. Ju, S. Yang, J. Park, and H. Na, "Pullout characteristics of geosynthetics reinforced earth using multi-layer pullout test," in Proceedings of the Spring Geosynthetics Conference, 2016. 
[17] I. Juran and C. L. Chen, "Soil-Geotextile Pull-out Interaction Properties, Testing and Interpretation, Transportation Research Record," 67th Annual Meeting, 1988.

[18] S. R. Brand and D. M. Duffy, "Strength and pullout test of geogrids," in Proceedings of the Geosynthetic Conference, vol. 1, pp. 226-236, New Orleans, 1987.

[19] G. E. Bauer, A. Halim, and Q. Shang, "Large-scale pullout tests: assessment of procedure and results," in Proceedings of the Geosynthetics '91 Conference, pp. 615-627, Atlanta, USA, 1991.

[20] K. Farrag, "Pull-out testing facility for geosynthetics," LTRC Project No. 87-1GT, Lousiana Transportation Research Center, U.S. Department of Transportation, Federal Highway Administration, 1991.

[21] J. H. Kim, Development and Applicability of Multi-layer Pullout apparatus System [Ph.D thesis], Sunchon National University, 2008.

[22] S. B. Yang, Pullout Characteristics of Geosynthetics Reinforced Earth using Multi-layer Pullout Test [Ph. D thesis], Sunchon National University, 2015.

[23] J. M. Kwag, The Reappearance of Relative Density by the Multiple Sieving Pluviation Method [M.S. thesis], Sunchon National University, 1994.

[24] H. Ochiai, N. Yasufuku, H. Yamaji et al., "Experimental evaluation of reinforcement in geogrid-soil structure," in Proceedings of the international symposium on earth reinforcement, pp. 249254, 1996.

[25] M. Koutsourais, D. Sandri, and R. Swan, "Soil interaction characteristics of geotextiles and geogrids," in Proceedings of the Geosynthetics '98, pp. 739-744, 1998. 

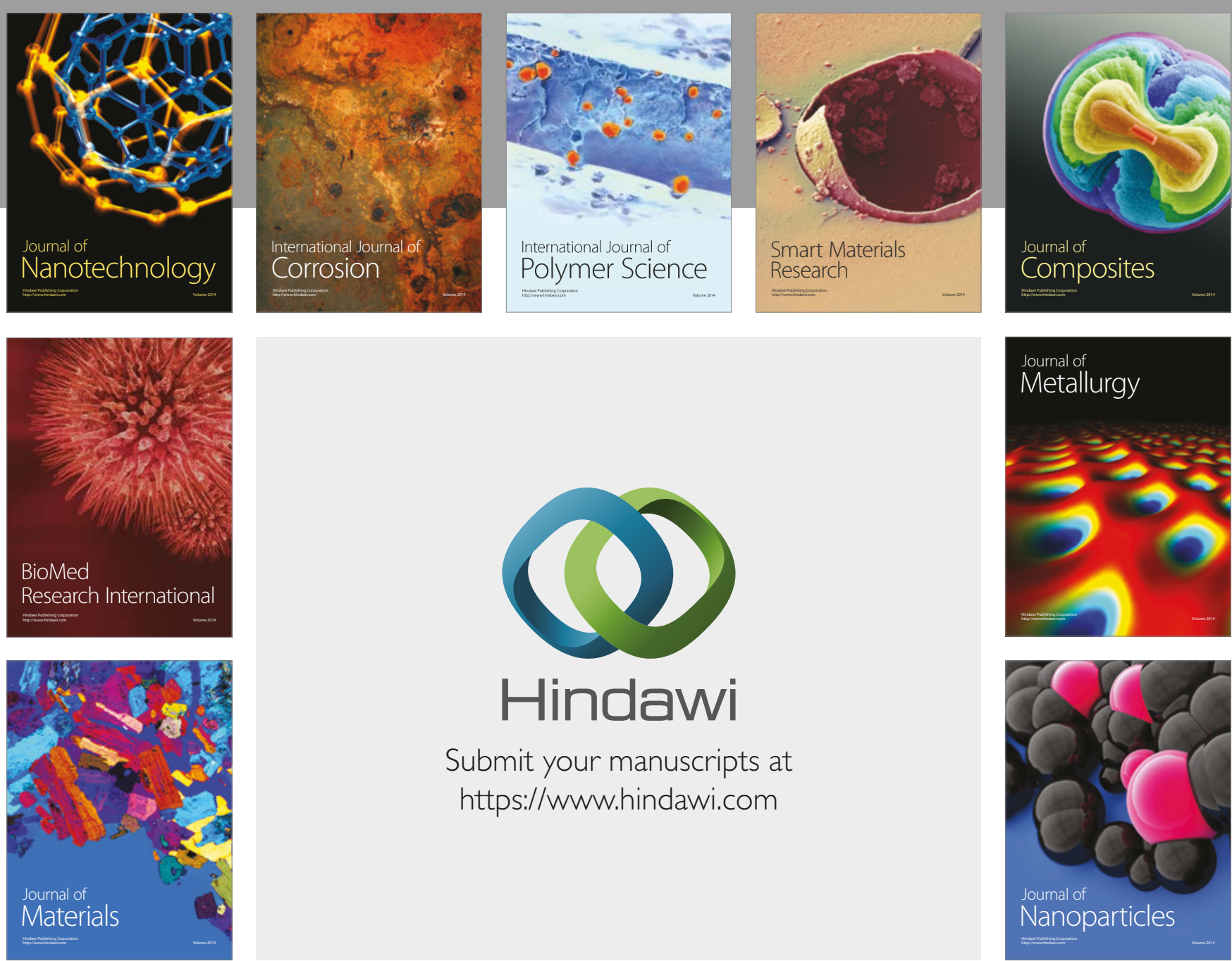

\section{Hindawi}

Submit your manuscripts at

https://www.hindawi.com
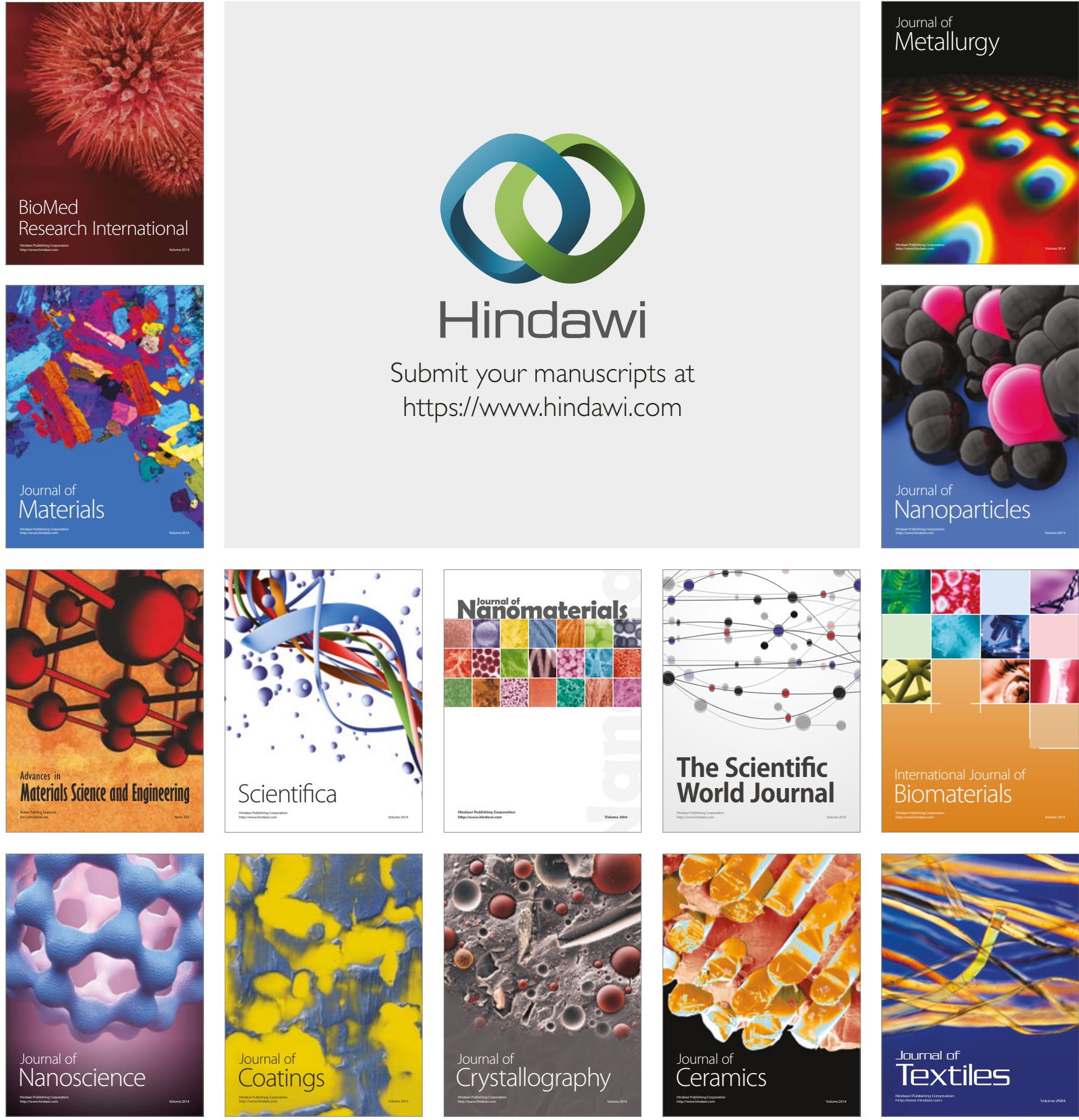

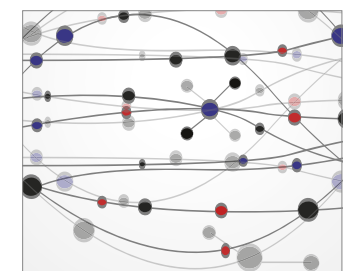

The Scientific World Journal
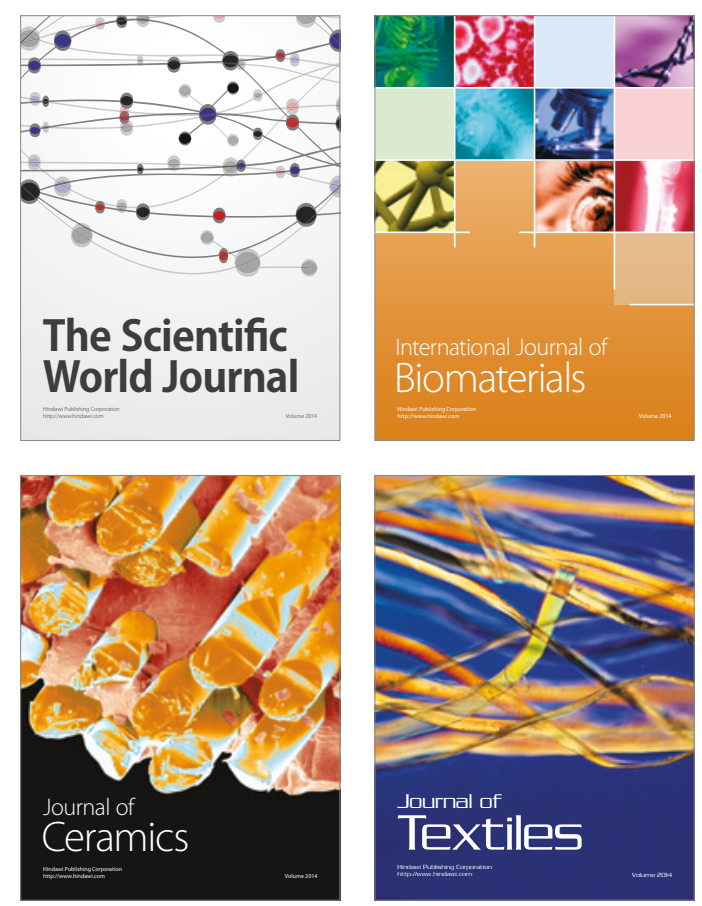